\title{
GEOLOGY
}

UDC 551.24: 553.98

Ye. Yu. Pogorelova, Cand. Sc. (Geol.-Miner.), Assoc. Prof., orcid.org/0000-0002-6195-1761
DOI: $10.29202 /$ nvngu/2019-1/1

Azerbaijan State Oil and Industry University, Baku, Azerbaijan, e-mail: yy_pgrlova@mail.ru

\section{GEOTECTONIC ASPECTS OF OIL AND GAS POTENTIAL OF THE INTERMOUNTAIN SEGMENT OF THE BLACK SEA-CASPIAN SEA REGION}

Purpose. To identify potential places of hydrocarbon accumulation in the Black Sea-Caspian Sea region.

Methodology. To achieve this goal, the author used the methods of retrospective analysis, review and comparison. With the help of the retrospective analysis, it became possible to determine that the crustal structures of this region are in close interaction with the border areas and have passed a long geological way of development, but all of them are united by the presence of hydrocarbon accumulations.

Findings. The methods used allowed studying the development of each major element of the Black Sea-Caspian Sea region and making conclusions about the prospects of its oil and gas potential. For example, in the modern structural plan of the Low Kura depression, the local gravitational Navaghi maximum of submeridional stretch was revealed. It emphasizes the relatively shallow occurrence of dense rocks composing the island arc series. It is established that the Georgian part of the Middle Kura depression smoothly passes into the Azerbaijan territory of the Middle Kura depression where terrigenous-carbonate and volcanogenic Meso-Cenozoic deposits are discovered. Small accumulations of oil in thin sand reservoirs of the Eocene were also identified.

Originality. The presented study showed the prospects for the development of oil and gas regions within Western Azerbaijan, since there are found anticline folds, which indicate the old age of origination. This suggests that they had been formed before the migration of hydrocarbons and could be the place of their localization. It is established that in Georgia, the prospects for the discovery of oil and gas fields are associated with Neogene and Paleogene upperCretaceous structural floors and access to the Black sea shelf.

Practical value. Analysis of the development of the depression part of the Black Sea-Caspian Sea region allows identifying regions where hydrocarbon accumulation is possible, which is of practical significance.

Keywords: Black Sea-Caspian Sea region, Riony Basin, Kura Basin, South-Caspian Basin, West-Turkmenian Basin, hydrocarbons

Introduction. The Black Sea-Caspian Sea region is the territory of a large area of the earth's surface of adjacent geological megastructures of different order, age and origin. It includes the water area of the Black and Caspian seas (partly), the orogens of the Great Caucasus and Lesser (partly) Caucasus, the Crimea, as well as the Azov-Kuban, Riony, Kura and West-Turkmenian hollows bordering and dividing these structural units. All the above-mentioned tectonic elements themselves are components of megastructures such as the AlpineHimalayan fold belt and the Scythian-Turanian epiHercynian platform.

All independent structures of the earth's crust of this region are in close interaction with the border areas and have passed a long geological way of development: at times it was common, sometimes separate, but they are all united by the presence of hydrocarbon accumulations.

(C) Pogorelova Ye. Yu., 2019
The intermountain segment of the Black Sea-Caspian Sea region includes the depression territories of Georgia, Azerbaijan, the shelves of the Black (Eastern part) and Caspian (Southern part) Seas and the WestTurkmenian hollow.

Tectonically, this territory is confined to the intermountain trough, located between the mountains of the Great Caucasus and Lesser Caucasus, the Great Balkhan and the Kopet Dagh, with which the South Caspian oil and gas potential megabasin is connected (Fig. 1). The oil and gas potential of the Black Sea-Caspian Sea region is associated with its confinement to the active margin of the Tethys ocean, which, a priori, indicates the presence of hydrocarbon accumulations. As an example, the West Siberian, Pre-Ural, pre-Cordillera and other oil and gas potential basins (the ancient active margins of continents) can be cited.

General characteristics of the Black Sea-Caspian Sea region. The rocks from Precambrian to modern ones 


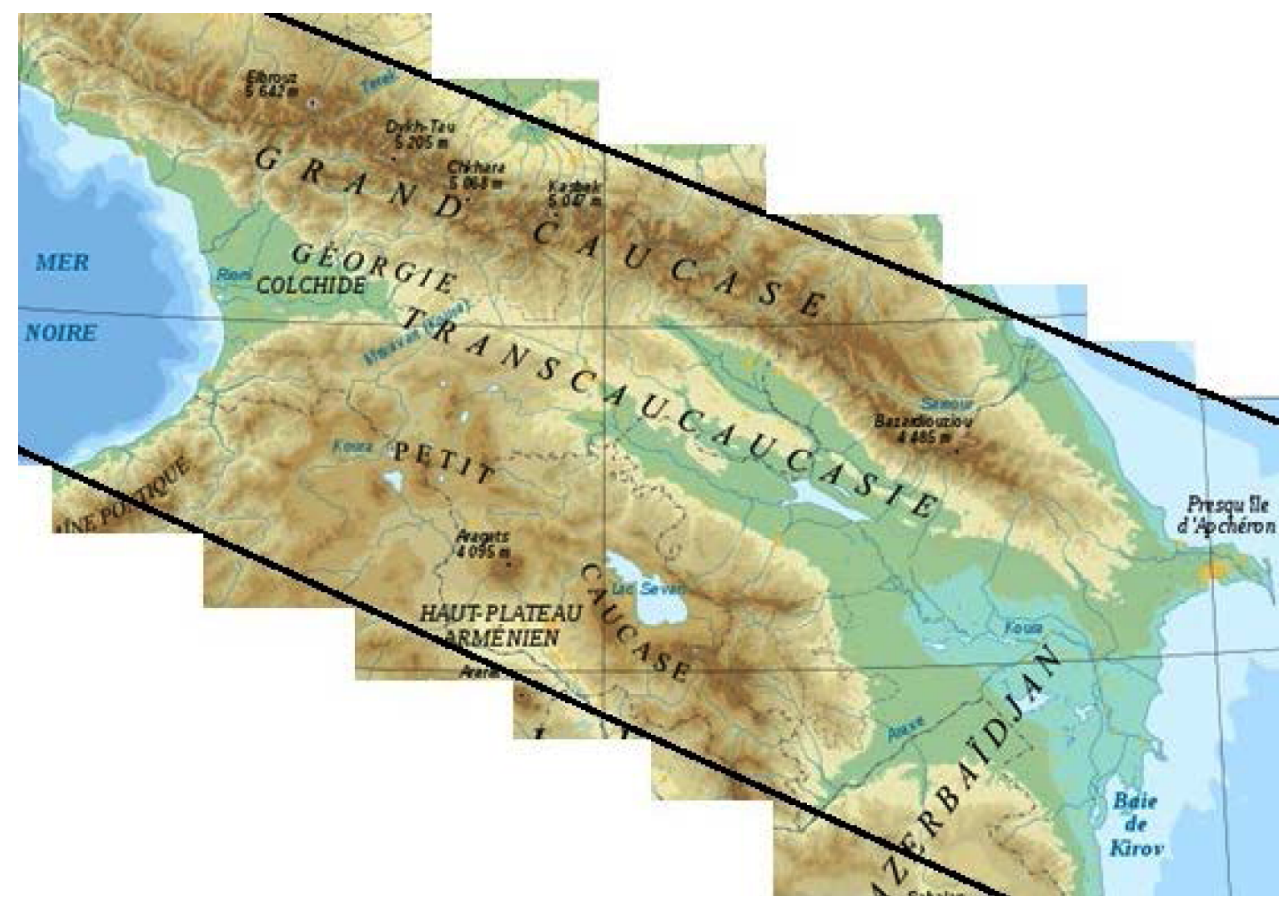

Fig. 1. Black Sea-Caspian Sea region with main tectonic elements

with different origin - magmatic, metamorphic and sedimentary - take part in the structure of the studied oil and gas potential basin. They are divided into three structural levels: Baikal, Hercynian and Alpine. The crystalline basement of the Baikal age is represented by strongly metamorphosed crystalline rocks of the Precambrian and the Cambrian, which emerge on the Earth's surface fragmentarily on the southern slope of the Great Caucasus.

On the territory of Georgia, the Hercynian crystalline basement is exposed on the Lock, Khramy and Dziruly Massives, and also forms the core of the anticlinorium of the Great Caucasus. In the allochthonous occurrence, the Hercynian metamorphic rocks are sometimes exposed as part of the ophiolitic melange in Amasia and on the Zod pass [1]. The main complex Alpine, is represented by large sedimentary deposits of Meso-Cenozoic age in the thickness of 3-9 km, with which the industrial oil and gas potential of the territory is associated. The intermountain megadepression, extending from the west, from the Black Sea coast, to the east, to both shores of the Caspian Sea, is represented by the Riony, Kura, South Caspian and West-Turkmenian depressions.

The territory under consideration in the Mesozoic was an active continental margin of Eurasia (island arc, marginal sea of the southern slope of the Great Caucasus) and was in a state of compression associated with the approach of Gondwana to Eurasia. This system is the island arc. V.E. Khain mentioned a widespread manifestation of vertical movements in the convergence zone of plates [2].

The territory under study is the convergence zone of the Eurasian and Arabian plates in which there occurred the transformation of horizontal movements into vertical ones, expressed in differentiated movement of blocks, development of elevations and deflections limited by deep faults, which sometimes had the character of seismic focal zones, in the inversion of elevations and deflections, in the sign-instability of movements on faults.

The Georgian part of the intermountain depression from east to west is represented by the Upper Kura and Riony depressions (Fig. 2), separated by Dziruly ledge of the Hercynian basement. The depressions are made of thick layers of Miocene-Pliocene molasses (up to 2$3 \mathrm{~km})$ and Paleocene-Eocene volcanogenic-terrige-

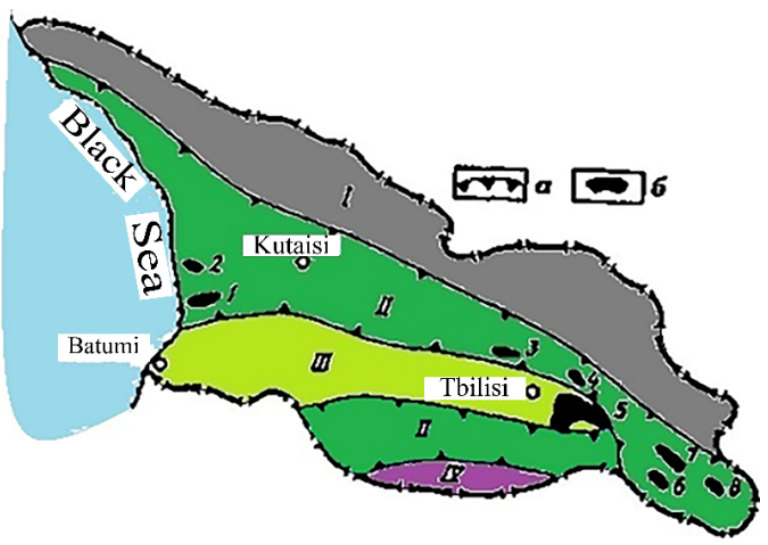

Fig. 2. Schematic tectonic map of Western Georgia with oil and gas fields [3]:

$a$ - boundaries of tectonic elements; $b$ - place of accumulation of hydrocarbons. The main tectonic elements: I fold system of the southern slope of the Great Caucasus; II - Transcaucasian microcontinent; III - Adjaria-Trialety superimposed folding; IV - Samkhety-Aghdam fold system. Place of accumulation: 1 - Supsa, 2-Eastern Chaladidi, 3 - Norio, 4 - Satskhei, 5 - Samghory-Patardzeuli, 6-Taribani, 7-Mirzaani, 8-Patara-Shiraki 
nous-carbonate formations up to $4.5 \mathrm{~km}$. It follows the shallow location of the foundation here; about 4-6 km.

On the sides of the Upper Kura (Kartly) depression in Neogene-Paleogene sediments, narrow, overturned to the south, disjunctively complicated folds are developed, since the Great Caucasus and Ajary-Trialety are thrust over the Kartly deflection; moreover, the intensity of the first thrust is more significant [4].

To the west of Kartly the Riony basin is located, which is revealed in the Black Sea water area (the Black Sea depression in the Cenozoic was an epirift molasse trough). It is presented, as well as the previous depression, mainly by terrigenous, volcanogenic-sedimentary and carbonate formations with a capacity of up to $12 \mathrm{~km}$ in age from Upper Cretaceous to Quaternary rocks. Three tectonic zones are distinguished within the limits of the Riony depression from the south to the north: Gurian, Colchian and Abkhazian-Mingrelian. The Colchian depression is superimposed, with the exception of the Central Mingrelian trough.

The Abkhazian-Mingrelian and Gurian troughs continue to the east by narrow depressions connecting them with the Kura depression, which in the OligoceneMiocene were straits connecting the Caspian and Black Sea basins [5, 6].

All the above-mentioned depressions are complicated by the brachymorphic folding of the Upper Cretaceous-Paleogene sediments.

The history of the development of the depression part of the Black Sea-Caspian Sea region. The main oil areas of Georgia are concentrated in the Colchian and South Kakheti oil and gas potential areas (intermountain troughs of the Transcaucasian microcontinent) and the Gurian and Pre-Tbilisy areas (marginal troughs of the imposed Adzharia-Trialety folded belt), the oil content of which is associated with sediments from the Upper Cretaceous to the Pleocene. Large oil fields of the Colchian tectonic zone - Western and Eastern Chaladidi, Supsa-Ompareti, and others [7].

The Colchian depression is mainly superimposed (with the exception of the Central Mingrelian trough), since during the Cenozoic there was often an inversion in relation to the paleotectonic elements developed in the Mesozoic. So, for example, the Riono-Chaladidi trough, which occurred in the Late Jurassic, was already disbanded in the Late Cretaceous and re-regenerated only in the Pliocene. In the early Middle Jurassic time, the GagraMukhury, Ritsa-Sory and Chokhataury deep faults are fixed, in the early Cretaceous the submeridional Sagvamichao-Tsalendzhikhy deep fault is fixed, in the later Cretaceous the Kobuleti-Zakary and Anaklia-Dzhvary deep faults are fixed. Along these faults, alternating movements of the blocks of the Earth's crust took place, which led to the dissolution of troughs and elevations.

In the early-middle Jurassic, a single Colchian trough develops, in the Late Jurassic the MingrelianAbkhazian and Low Riony-East-Black Sea troughs develop with the Gudauto-Khoby elevation that separates them.

The early Cretaceous situation clearly shows the absence of inheritance and the manifestation of differen- tiation in development within the territory of the Colchian depression. The following elements are evolving: Tsaishy, South Khoby, Tsalendjikhy, Lessy elevations, Mingrelian, Riony-Chaladidy deflections. All these elements have a Caucasian strech. But even in the Late Cretaceous, there are elements with a submeridional stretch - the Salkhinoyi, Okumy elevations, the Central Mingrelian, Saberian deflections. At the same time, elements of the Caucasian stretch are developing - Guriysmteby elevation, Mokva-Gagra and Guriy deflections [8]. All these changes in orientation in space and in time of large geological elements are associated, of course, with the main driving forces - the rapprochement of Gondwana and Eurasia.

In the Paleocene - Eocene and Oligocene - Early Miocene time, the submeridional Central Mingrelian trough continues to develop; to the west, east, north and south of it in the Eocene-Paleocene time the SalkhinoKvalony, Dziruly, Caucasus, Lessy elevations are located, and in the Oligocene-Early Miocene time in the western part of the Colchian depression a vast Colchian elevation appears, which included the territory existing in Paleocen-Eocene of Salkhiny-Kvalony and Lessy elevations. The Colchian elevation was a zone of erosion, stretching to the Black sea in the north-west, forming the vast Colchian-East-Black Sea elevation - land [8].

In the Middle Late Miocene time, superimposed Supsa deflection occurs, as a result of which the area of the Colchian-East-Black Sea elevation - land decreases, which is displaced to the north compared to the Oligocene-Lower Miocene time. At the same time, the Central Mingrelian trough continued to develop consistently, laid down in the Late Cretaceous time.

During the Pliocene time, within the limits of the Colchian depression, the Supsa and Central Mingrelian troughs were disbanded, in their place the Guriysmteby elevation (which existed in the early Cretaceous time, and later became part of the more extensive ColchianEast-Black Sea land) and the Colchian elevation appeared, pushed back to the east and constituting a single area of erosion with the Dziruly land [7].

As mentioned above, the Rioni-Chaladidi trough reappears in the Pliocene. Finally, in the Quaternary time, the Central Mingrelian trough reappears, which ceased to exist in the Pliocene. The history of the geological development of the western part of the intermountain trough of the Black Sea-Caspian Sea region determines the areas of formation of sources of oil and gas source rocks and hydrocarbon accumulation zones.

To the east of the Kartli depression, the Middle Kura depression with complex tectonics extends, especially between the Kura and Iori (Gabyrry) rivers. Here, the South Kakheti tectonic region is distinguished with great power of the Paleogene-Neogene $(4-5 \mathrm{~km})$ and the Mirzaani-Areshy meganticlinorium, in which the powerful Pliocene complex is deployed in folds, broken by thrusts.

The southern part of the Transcaucasian microplate (island arc) took place in the Late Mesozoic and Cenozoic geosynclinal mode of development, as a result of which Cretaceous-Paleogene deflections (rifts) with 
structural and formation zones formed at the junction with the meganticlinorium of the Lesser Caucasus (island arc in the Mesozoic): Ajary-Trialety, Bolnisy (Bolnisy-Ganja) and Sakiry (Sakiry-Lory). The far northern subsidence of some of them are part of the intermountain trough [2]. Unaffected by this regeneration, a relatively stable tectonic block remained - the ArtvinBolnisy block, within which the projections of the ancient basement - the Khramy and Locky massifs remained.

The Georgian part of the Middle Kura depression smoothly passes into the Azerbaijan territory of the Middle Kura depression, where terrigenous-carbonate (Naftalan, Terter, Ghazanbulag, etc.) and volcanogenic (Muradkhanly) Meso-Cenozoic deposits are discovered. Small accumulations of oil were found in thin sandy reservoirs of the Eocene (foraminiferal layers) and Oligocene-Miocene (Maikop formation) in the areas of Naftalan, Ghazanbulag, Terter, Ajidere. All of these areas of oil and gas belong mainly to Pre-Lesser Caucasian and Yevlakh-Agjabedy deflections, although tectonically Middle Kura depression presented by Alazany-Agrichay superimposed synclinorium, AmirvanDashyuz anticlinorium, Mirzaany-Areshy synclinorium, Chatma-Geychay anticlinorium, Palantekian synclinorium. The Stretch of these structures is Caucasian [9]. The heterogeneity of the structure of the Middle Kura depression, as well as the Riony and Upper Kura depressions, is explained by its presence in the front of converging plates with active tectonics, including volcanism, folding activity, breaks and sedimentation.

The Middle Kura and Western Turkmenian depressions were laid on blocks continuing to sag in Cenozoic of Ajary-Trialeti, Lesser Caucasus, Prebalkhanian zone and the zone of south-western virgations of Kopetdag. The Kura depression, in essence, is a molasse, but mostly unstrained trough. Within its limits, the Gabyrry (Iori) (Late Cretaceous), Alazani-Agrichay (Pliocene) and Sabirabad (Quaternary) deflections are superimposed.

After the collision in the Bathonian time of the Samkhety-Agdam and Central-Kura island arcs, the territory of the Kura depression and the Samkhety-Agdam region were part of a single Transcaucasian island arc, or, in the narrower sense, of the Lesser Caucasian [3]. However, the age range of volcanism within the territory of the Kura depression is wider than in the SamkhetyAgdam zone. Here, in addition to the Late Jurassic, Coniacian-Santon volcanism, which is also characteristic of the Samkhety-Agdam zone, there is also an Albian-Cenomanian characteristic of the Vandam zone and Ajary-Trialeti, as well as Campanian volcanism characteristic of the Vandam zone [10].

Drilling data revealed that the raised Mesozoic zone from the Kyurdamir-Saatli buried elevation area does not extend in the direction of the Vandam zone to the north, but turns in the west-north-west direction, corresponding to the Mingyachevir-Geychay gravity maximum. The Mingyachevir-Geychay-Kyurdamir-SaatlyMughan gravity maximum system emerges, which in the Mingyachevir-Geychay segment has Caucasian stretch, and in the Kyurdamir region it acquires a submeridional stretch. This entire system of maxima is blocked from the north (in the western part) and from the east (in the eastern part) of the Mingyachevir-Geychay-PadarGhyzylagach (Mingyachevir-Geychay-Western-Caspian) system of deep faults, which is the boundary of blocks with developed and undeveloped granite layer i.e. the ensialic and ensimatic blocks [3] (Fig. 3).

The above-mentioned maxima within the Kura depression even in the Mesozoic form elevations and deflections, which further develop during the entire MesoCenozoic. So, even in the early Jurassic, MingyachevirGeychay-Kyurdamir-Saatly-Mughan, Alazan-Agrichay elevations, Shirak-Ajinohur-Low Kura, Yevlakh-Agjabedi deflections [12] occur, which developed before the Pliocene. In the Pliocene, only the Shirak-Ajinohur-Low Kura trough is preserved. The Yevlakh-Agjabedi trough is disbanded, here at this time structural projections of the anti-Caucasian strike are formed, but at the Quaternary the Yevlakh-Agdzhabedi trough reappears [3].

Long-lived faults are developed - Lenkoran-Lagodekhi, West Caspian, Mingyachevir, Geychay-PadarGhyzylagach, Orkhevi-Ajichay-Alyat, Telavi-Ismayilli, Kvareli-Gutkashen systems of Bilyasuvar-Karadonly and Mukhran-Siony transverse faults, Sheki-Yevlakh cross fault. The Bilyasuvar-Karadonly cross faults system (Lower-Araks) limits the Bilyasuvar-Karadonly cross elevation (West Caspian, according to E. Sh.Shikhalibeyli) from the north and south. This elevation is crucial in the formation of various historical and structural frameworks in the Eocene time within the Samkhety-Agdam zone of the Lesser Caucasus and Talysh. This system of faults is connected with the deep fault, which passes in the central part of the Kyurdamir-Saatli elevation, cutting off Talysh from the Samkhety-Agdam zone of the Lesser Caucasus.

The Middle Kura depression, expanding to the east, passes into the Low Kura depression, which reveals the

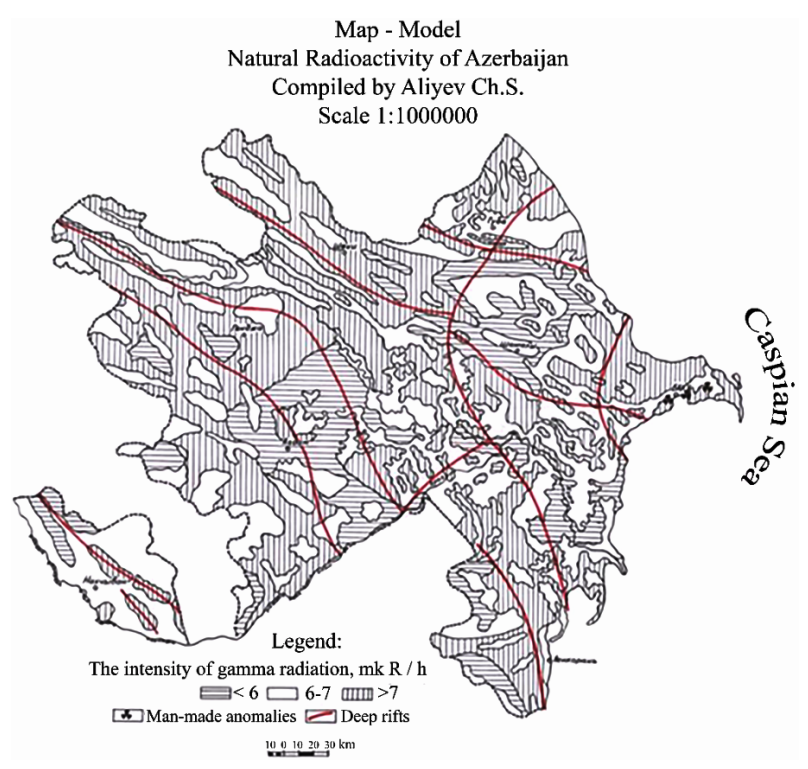

Fig. 3. Deep faults of Azerbaijan [11] 
Low Kura trough, separating the Talysh folded belt from the Lesser Caucasus.

The Low Kura depression is the widest part of the intermontane trough, made of $10 \mathrm{~km}$ by molasse, mainly due to the occurrence of Lower Pliocene continental sediments in the section - an analogue of the "productive strata". This whole complex of formations, including the lower quaternary layers (Absheron), forms chains of brachyanticlinal folds (Kyurovdag, Neftchala, Kyursangi, and others) disturbed by discharges and mud volcanoes.

In the modern structural plan of the Low Kura depression, the local gravitational Navaghy maximum of the submeridional stretch is a reflection of the existing ensialic island arc. These maxima emphasize the relatively shallow occurrence of dense rocks composing the island arc series. The border of the Low Kura depression with the Great Caucasus is expressed in the same way as its entire southern side, by pushing the latter to the edge of the depression. In the west it is more flat-lying, where Pliocene molasses are set on the head in the lying side of the thrust, in the east it is steeper.

To the east, the Low Kura depression is revealed into the basin of the Southern Caspian as an oil and gas potential region of the Baku archipelago, as well as the southeast end of the Shamakha-Gobustan synclinorium, more precisely, its southern extremity, the Lengebiz-Alyat ridge. As mentioned above, almost all structures are brachy-anticlinal folds, complicated by faults and mud volcanoes with a sedimentary capacity of more than $20 \mathrm{~km}$.

The island arc, limiting the depression of the Southern Caspian from the north, is the eastern continuation of the ensialic island arc, which was established, as mentioned above, within the Vandam zone; in the modern structural plan, its reflection is the Sangachal submeridional section of the Yavandag-Sangachal gravity maximum and the local gravitational maximum of the Baku archipelago [13].

All of the above reflects the tendency to change the stretch of the eastern elements of the Kura depression from the Caucasus to the submeridional. This trend is also evident for elements of the Vandam zone. It was also detected by geophysics to the south of the Absheron peninsula. These eastern elements of the Kura depression and the Vandam zone go to the western part of the depression of the Southern Caspian, and elements of the West-Turkmenian depression go from the east. These elements of both depressions are often interconnected within the depression of the Southern Caspian. Thus, the Absheron-Pre-Balkhanian trough develops in the north of the southern Caspian depression in the mesoCenozoic, Kyurdamir-Saatly-Mughan elevation through the depression of the Southern Caspian is connected to the Godin elevation, and the Jalilabad trough is connected to the Keymir-Chikishlyar trough [14].

The Absheron archipelago is located north of the Baku archipelago - a continuation of the south-eastern end of the Great Caucasus into the sea, namely, the Absheron peninsula (Fig. 4), which in the sea is connected to the Pre-Balkhanian elevation zone in the eastern part

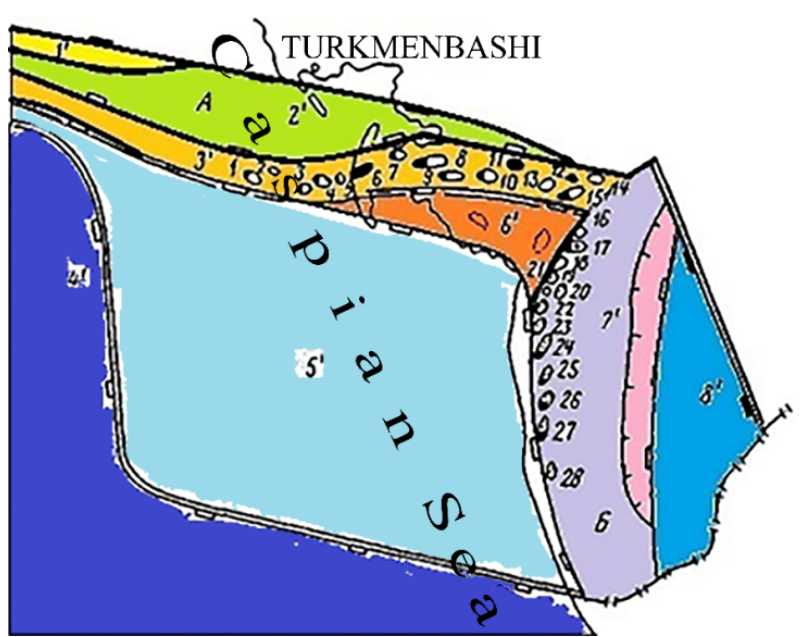

Fig. 4. Overview map of the location of oil and gas sites in the West Turkmen Basin [6]:

Large tectonic elements: 1 ' - North Absheron uplift zone; $2^{\prime}$ - Pirallahi-Kelkor deflection; $3^{\prime}$ - Absheron-PreBalkhanian zone; 4' - South Caspian Basin; 5' - Turkmen Step; 6' - Kyzylkum Trough; 7' - Gograndag - Okarem Rise Zone; $8^{\prime}$ - Aladag - Messarian Step. Oil and gas bearing areas: $A$ - Absheron-Pre-Balkhanian; $B$ - West Turkmen

of the Caspian, forming a single tectonic structure Absheron-Pre-Balkhanian, separating the South Caspian and Mid-Caspian depressions.

The sandy-clay layers of the "productive strata" of the lower Pliocene of the Absheron peninsula in the interval of depths from 200 to almost $4 \mathrm{~km}$ contain hydrocarbon deposits. These layers, plunging to the southeast, in the Caspian waters to a depth of 5-6 km, are productive, and the largest deposits are currently discovered: Shah Deniz, Absheron block, Gharabakh, Azeri, Chirag, Gunashli and others.

All structures located in the western part of the South Caspian belong to the Azerbaijani sector of the Black Sea-Caspian Sea region. However, moving in the eastern half of the waters, folds buried under the sea bottom make up the folding of the West Turkmenian depression, confined to the intermountain depression located between the mountain structures of the Alpine folding of the Big Balkhan, Kopet-Dag and Albours.

As with the entire South Caspian megadepression, it is characterized by a high thickness of the Meso-Cenozoic sediments (15-20 km in its central parts), manifestation of plicative and disjunctive dislocations, linear folding, and the presence of mud volcanism [11].

The main tectonic elements of the West-Turkmenian depression - closing Black Sea-Caspian Sea region in the east - are the Pre-Balkhanian, Gograndag-Okarem zones of elevations and the deep Kyzylkum deflection separating them.

In the eastern part of the depression, the AladagMessarian step is distinguished, corresponding to the immersion of the Mesozoic folding of the Western Kopetdag.

Absheron-Pre-Balkhanian zone of elevations extends in a sub-latitudinal direction in the northern part 
of the depression and is represented by anticlinal structures (Cheleken, Kotur-Tepe, Barsagelmes, etc.), plunging into the Caspian Sea (Banka Zhdanova, Banka Gubkina, LAM, and others), and connecting with the Absheron threshold stretching out to it.

The Gogranydag-Okarem zone of elevations extends in a submeridional direction parallel to the coast of the Caspian Sea. In contrast to the folds of the Prebalkhan zone, the folds of this zone are flat with wide arches, with small amplitude and a smaller disturbance. The morphology of these folds leads to the conclusion about their genesis. First, their orientation indicates their dependence on the near-meridian (West Turkmenian) fault, which forms the folding processes (these disturbances in the Neogene sediments correspond to discharges, which, in turn, involve numerous mud volcanoes). Secondly, the forms themselves and the amplitudes of the folds confirm their origin, most likely, from the vertical forces of the Earth's crust, and not from the horizontal ones.

The Kyzylkum trough is located between the Absheron-Pre-Balkhanian and Gogranydag-Okarem zones of elevations and is affected by the tangential and radial forces of the Earth's crust in this segment of the West-Turkmenian basin. This is explained by the fact that the deflection develops in the zone of interaction of small plates of the Earth's crust both along the shear boundaries and along deep, crustal faults, which is reflected in the genesis of folding and its orientation in space. Namely, the Absheron-Pre-Balkhanian zone of elevations, limiting the deflection from the north, is a reflection of the subduction zone of the South Caspian microplate under the Eurasian plate in the sedimentary cover [15]. The Gogranydag-Okarem elevation zone, which limits the deflection from the south-east, borders on the Kyzylkum deflection along the shear, which ultimately controls its folding in the Neogene-Quaternary layers (Fig. 5). At the border with the shear, suture zone, the folds have a near meridional orientation; orientation of the folds in the central and northern parts of the trough are close to latitude.

The eastern-most tectonic unit of the South Caspian hollow - the Aladak-Messarian tectonic zone - is an area of the buried Mesozoic folding, plunging to the west, towards the Gogranydag-Okarem zone of elevations along a system of large, stepped nature, deep faults, to the west of which there are sediments of the "red strata", which are absent in the Aladak-Messarian zone [16].

Regarding the oil and gas potential of the WestTurkmenian depression, all identified sites (Pre-Balkhanian and Gogranydag-Okarem oil and gas field) belong to the "red (productive) strata", where they are also multilayer, Akchagyl and Absheron tiers of the upper Pliocene and Quaternary [13].

Conclusions. Having considered the history of the geotectonic development of the intermountain depression of the Black Sea-Caspian Sea region, following the development of each major element of the region in stages, we come to the following conclusions:

1. Up to the lower Cretaceous, inclusive, there was an Artvin-Bolnisy elevation (terrain at the place of the Kura and Gabyrry (Iori) interfluve).

2. Up to the Maykop, there was a trough of the PreTbilissi area (submerged zone of Adzharia-Trialetia). In this regard, the prospects for the discovery of oil and gas fields in Georgia are associated with the Neogene and Paleogene-Upper Cretaceous structural floors and access to the Black Sea shelf.

3. Within the limits of the Kura depression, the Gabyrry (Iori) (Late Cretaceous), Alazany-Agrichay (Pliocene), Sabirabad (Quaternary) deflections and the Araks cross deflection are superimposed.

4. In the Cretaceous-Oligocene time the BilyasuvarCaradonli elevation developed, and only in the Miocene was the Lower-Araks cross deflection formed.

5. The Meso-Cenozoic elevations and depressions in the eastern part of the Kura basin change their stretch

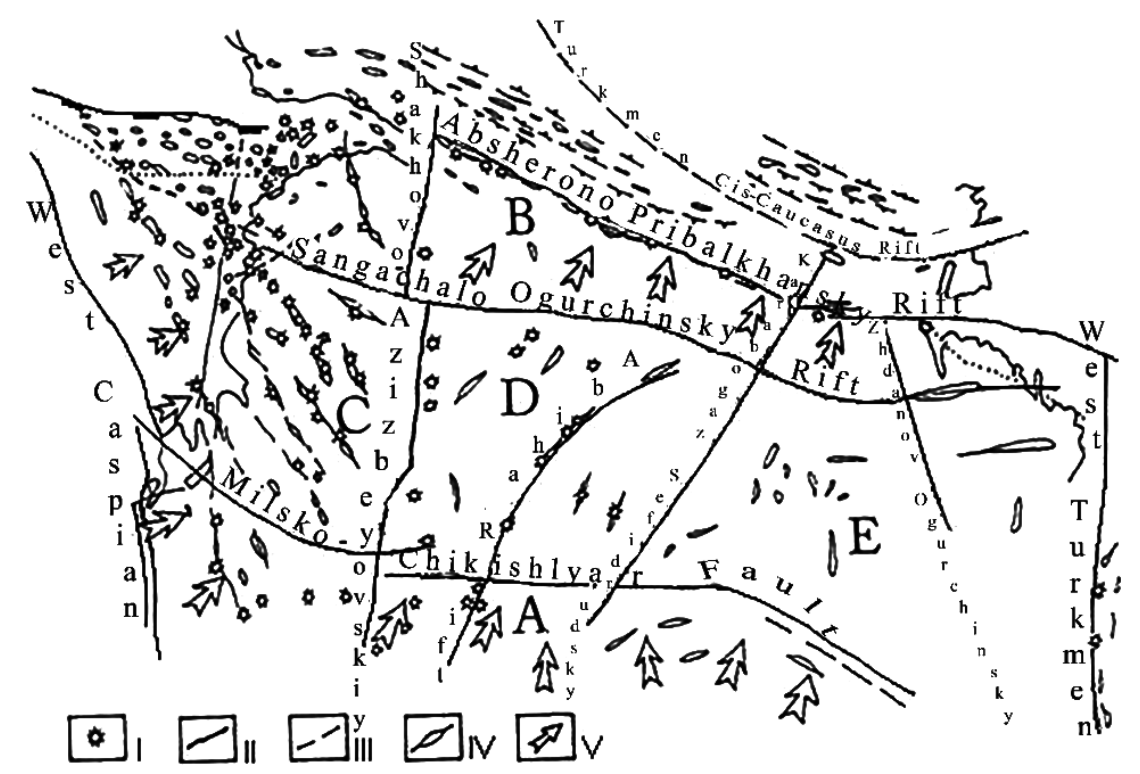

Fig. 5. Fault tectonics of the South Caspian basin [15] 
from the Caucasus to the submeridional and go into the depression of the South Caspian. The Mesozoic elements in the West Turkmenian basin have the same stretch.

6. In connection with this change in stretch, it is improper to speak about a single Talysh-Vandam submeridional elevation, even not least because the Mingyachevir-Geychay gravitational maximum is separated from the Vandam maximum by the Ajinohur minimum, and the Mughan gravitational maximum goes to the South Caspian, reaching Talysh.

7. Up to the Pliocene, the Kura depression was mainly molasse, but not overlapped deflection, and the Low Kura deflection also developed later, and only in the post-Baku time a modern relief was formed here.

Based on the study of the correlation of structural plans for the folding of the Kura depression, it is possible to conclude that the prospects of structural ledges of the anti-Caucasian direction within the Western Azerbaijan (the area between the Kura and Gabyrry) are promising. The structural ledges of the anti-Caucasian direction and the same direction of the anticlinal folds indicate the antiquity of the foundation, which, in turn, indicates that they were already formed by the time of the migration of hydrocarbons and could be the place of their localization. In this regard, volcanic-sedimentary formations of the Eocene and Upper Cretaceous, which have good reservoir properties, can be promising in terms of oil and gas potential.

The structural plan of the Miocene (Sarmatian deposits) between the rivers Kura and Gabyrry is represented by linear folds of the Caucasian stretch. Within the Kyurdamir-Saatli elevation, both the correspondence of structural plans of the Cretaceous-Paleogene and the Miocene (Jarli, Muradkhanli, Sorsor folds), and their discrepancy (Amirarch, West Amirarkh, Mursala folds) are noted.

The Pliocene-anthropogenic structural plan of the central part of the Kura depression is characterized by monoclinal immersion of the complex structure in the direction of the Kura depression and by the presence of separate structural noses, where local anticlinal folds are fixed along deeper horizons.

Inherited subsidence zones can be promising in terms of oil and gas content, as they have a continuous section of sediments. Such zones are the Absheron peninsula, the Low Kura depression, the Shirak-Ajinohur zone.

In the West Turkmenian depression, a structural change occurred in the Paleogene. The modern structural plan within its limits is formed from the Pliocene. The oil and gas potential, both discovered and promising, is associated with Paleogene ("under-colored") terrigenous and Neogene-Quaternary sediments.

\section{References.}

1. Aghamalyan, V.A., 2015. The Hakhum mass as a Hercynian crystal base salient for Armenia's NorthEastern part. Proceeding of NAS of RA. Earth Sciences, 2, pp. 3-12.

2. Lomakin, I. E., Anokhin, V. M., Kochelaab, V. V., Pokalyuk, V. V., Shafranskaya, N. V. and Shuraev, I. N.,
2016. Tectonolines and some geotectonics. Geotectonics, 3, pp. 59-75.

3. Pogorelova, E. Yu. and Serikova, U. S., 2010. Paleotectonic reconstruction of the development of the PreLesser Caucasus Trough in order to identify promising oil and gas objects. Oil, Gas and Business [pdf], 2, pp. 37-41. Available at: <http://ngb.gubkin.ru/curentnum/image/12_10/9.pdf $>$ [Accessed 23 October 2017]. 4. Manilov, Yu. F. and Kaplun, V. B., 2017. Deep rifts of the Northern Sikhote-Alin according to geophysical data. In: Materials XLIX Tectonic meeting dedicated to the $100^{\text {th }}$ anniversary of Academician Yu.M. Pushcharovsky. Moscow: GEOS [pdf], pp. 3-6. Available at: <http:// www.ginras.ru/materials/files/MTK_2017_Tom\%202_ internet.pdf $>$ [Accessed 5 January 2018 .

5. Leonov, Yu. G., Volozh, Yu.A. and Antipov, M.P., 2015. Oil of deep horizonts of sedimentary basins of Russia and adjacent countries. Monitoring: Science and Technology, 4, pp. 6-15.

6. Vorobev, A.E., Moldabayeva, G.Zh., Oryngozhin, E.S. and Chekushina, E. V., 2013. Aquatic deposits of gas hydrates: resources and innovative technologies of development. Almaty: Institute of Geology and Oil and Gas Business named after K. Turysov [pdf], pp. 77-80. Available at: <http://portal.kazntu.kz/files/publicate/ 2015-10-24-11159.pdf > [Accessed 11 October 2017].

7. Lebedeva, V.A., Chugaev, A.V., Vashakidze, G.T. and Parfenova, A. V., 2016. Stages of formation and sources of ore matter from the Devdorak copper deposit (Kazbek volcanic center, Greater Caucasus). Geology of Ore Deposits, 58(6), pp. 522-543.

8. Glumov, I. F., Gulev, V. L., Karnaukhov, S. M. and Senin, B. V., 2014. Regional geology and oil and gas potential of the Black Sea deep-water depression and adjacent shelf zones. Moscow: Nedra.

9. Gadirov, V.G., Gadirov, K.V. and Bekirov, M.A., 2016. Local magnetic anomalies of the Middle Kurin Basin of Azerbaijan and their geological interpretation. Geophysical Journal, 38(6), pp. 146-153.

10. Arutyunyan, A. V., 2010. Earth crust of Lesser Caucasus, ophiolites, volcanism, oilgasbearing, seismisity. Vestnik Otdelenia Nauk o Zemle RAN [pdf], 2, pp. 44-53. Available at: <https://onznews.wdcb.ru/publications/ v02/2010NZ000024.pdf> [Accessed 24 September 2017]. 11. Ismail-Zade, A.D., 2016. The main problems and prospects of metallogeny of Azerbaijan in the XXI century. News of the Ural State Mining University, 4(44), 13-17.

12. Gurbanov, V.Sh. and Sultanov, L.A., 2015. On the oil and gas potential of Azerbaijan's Mesozoic sediments. Bulletin PNRPU. Geology. Oil and Gas and Mining, 16, pp. 7-13.

13. Murzagaliev, D. M., 2017. Caspian Sea: exploration and development of offshore fields. Geology, Geography and Global Energy, 4(67), pp. 21-32.

14. Wells, M., Morton, A. and Frei, D., 2017. Provenance of Lower Cretaceous clastic reservoirs in the Middle East. Journal of the Geological Society, 174, pp. 1048-1061.

15. Gurbanov, V.Sh., Sultanov, L.A., Narimanov, N. R., Babaev, M. S. and Alieva, T.A., 2018. The geological structure and results of petrophysical studies of deposits of the 
productive stratum (PT) of the Garasu oil field in the Baku archipelago under the conditions of the existing geodynamic regime. Mining and Geological Journal, 2, pp. 17-23. 16. Dadashev, F. G., 2016. On the issue of the source of oil and gas in the productive stratum of Azerbaijan. Azerbaijan Oil Economy, 2, pp. 3-5.

\section{Геотектонічні аспекти нафтогазоносності міжгірського сегменту Чорноморсько- Каспійського регіону}

\section{Є. Ю. Погорелова}

Азербайджанський державний університет нафти і промисловості, м. Баку, Азербайджан, e-mail: yy_pgrlova@mail.ru

Мета. Виявлення потенційних місць скупчення вуглеводнів у Чорноморсько-Каспійському регіоні.

Методика. Для досягнення поставленої мети автором використані методи ретроспективного аналізу, огляду й порівняння. За допомогою ретроспективного аналізу було визначено, що структури земної кори цього регіону знаходяться в тісній взаємодії з прикордонними територіями та пройшли довгий геологічний шлях розвитку, що об’єднує наявність скупчень вуглеводнів.

Результати. Використані методи дали можливість вивчити розвиток кожного великого елемента Чорноморсько-Каспійського регіону та зробити висновок щодо перспективи його нафтогазоносності. Наприклад, встановлено, що в сучасному структурному плані Нижньокуринської западини виявлено локальний гравітаційний Навагінський максимум субмеридионального простягання. Він підкреслює відносно неглибоке залягання щільних порід, що складають островодужну серію. Встановлено, що грузинська частина Середньокуриньскої западини плавно переходить у азербайджанську територію Середньокуриньскої западини, де розкриті теригенно-карбонатні й вулканогенні мезокайнозойські відкладення. Також виявлені невеликі скупчення нафти в малопотужних піщаних колекторах еоцену.

Наукова новизна. Наше дослідження виявило перспективність структурних виступів антикавказького напряму в межах Західного Азербайджану, оскільки там виявлені антиклінальні складки, що вказують на старовину закладення. Це говорить про те, що вони сформовані до моменту міграції вуглеводнів і могли бути місцем їх локалізації. Встановлено, що у Грузії перспективи відкриття нафтогазоносних родовищ пов'язані з неогеновими й палеоген-верхньомеловими структурними поверхами та виходом на шельф Чорного моря.

Практична значимість. Аналіз розвитку депресійної частини Чорноморсько-Каспійського регіону дозволив виявити регіони, де можливе накопичення вуглеводнів, що має практичну значимість.

Ключові слова: Чорноморсько-Каспійський регіон, Ріонськая западина, Куринська западина, ПівденноКаспійська западина, Західно-Туркменська западина, вуглеводні

\section{Геотектонические аспекты нефтегазоносности межгорного сегмента Черноморско-Каспийского региона}

\section{Е. Ю. Погорелова}

Азербайджанский государственный университет нефти и промышленности, г. Баку, Азербайджан, е-mail: уу_ pgrlova@mail.ru

Цель. Выявления потенциальных мест скопления углеводородов в Черноморско-Каспийском регионе.

Методика. Для достижения поставленной цели автором использованы методы ретроспективного анализа, обзора и сравнения. С помощью ретроспективного анализа стало возможным определить, что структуры земной коры этого региона находятся в тесном взаимодействии с пограничными территориями и прошли длинный геологический путь развития. И их всех объединяет наличие скоплений углеводородов.

Результаты. Использованные методы позволили изучить развитие каждого крупного элемента Черноморско-Каспийского региона и сделать выводы о перспективах его нефтегазоносности. К примеру, выявлено, что в современном структурном плане Нижнекуринской впадины выявлен локальный гравитационный Навагинский максимум субмеридионального простирания. Он подчеркивает относительно неглубокое залегание плотных пород, слагающих островодужную серию. Установлено, что грузинская часть Среднекуринской впадины плавно переходит в азербайджанскую территорию Среднекуринской впадины, где вскрыты терригенно-карбонатные и вулканогенные мезокайнозойские отложения. Также выявлены небольшие скопления нефти в маломощных песчаных коллекторах эоцена.

Научная новизна. Представленное исследование показало перспективность развития нефтегазоносных областей в пределах Западного Азербайджана, поскольку там обнаружены антиклинальные складки, которые указывают на древность заложения. Это говорит о том, что они сформированы до момента миграции углеводородов и могли быть местом их локализации. Установлено, что в Грузии перспективы открытия нефтегазоносных месторождений связаны с неогеновыми и палеоген-верхнемеловыми структурными этажами и выходом на шельф Черного моря.

Практическая значимость. Анализ развития депрессионной части Черноморско-Каспийского региона позволяет выявить регионы, где возможно накопление углеводородов, что имеет практическую значимость.

Ключевые слова: Черноморско-Каспийский регион, Рионская впадина, Куринская впадина, ЮжснКаспийская впадина, Западно-Туркменская впадина, углеводороды

Рекомендовано до публікації докт. геол.-мінер. наук Н. І. Бабаєвим. Дата надходження рукопису 13.11.17. 